\title{
The Challenge and Countermeasure of Internet Finance to China 's
}

\section{Payment System Supervision}

\author{
Ni Xue \\ Hainan Vocational College of Political Science and Law, Hainan, Haikou, 571100
}

Key words: Internet finance; payment system; regulation; challenge; coping strategy

\begin{abstract}
Internet finance is the completion of financial services in the network space, not only to significantly improve the efficiency of financial work, and users also enjoy a more convenient service. However, the Internet financial because it is running in the virtual network space, it is bound to pay the supervision and management system to bring some difficulties. This requires a corresponding response to ensure that the payment system is functioning effectively. This paper studies the challenges and coping strategies of Internet finance to China's payment system supervision.
\end{abstract}

\section{Introduction}

In 2014, Premier Li Keqiang in the "Government Work Report" proposed to promote the development of Internet financial requirements, which is the future development of the financial industry, the main way. Internet has the characteristics of open, the financial industry application of Internet technology, making the payment system has changed, to pay the supervision and management of the system to challenge. In order to ensure the effective operation of Internet finance at the same time, the payment system of the work smoothly, you need to take the necessary response measures. Through the effective implementation of the payment system to ensure the healthy development of the financial industry.

\section{The Internet finance on China's payment system supervision and management brought about by the challenges}

First, the payment system of external supervision and management environment is complicated, it will lead to the difficulty of supervision and management increased. At present, the interaction between the payment system and the financial market is increasing, and the competition between the market and the cooperation of the market is more intense, which leads to the challenge of the supervision and management of the payment system.

Second, the supervision and management of the payment system and the supervision and management of the environment there is a dislocation of the phenomenon, that is, internal supervision and management philosophy does not meet the external supervision and management environment, leading to supervision and management work can not be successfully launched. In the course of business development, the business should be carried out in accordance with the provisions. However, there are many risks in the course of business operation. Although the relevant departments have carried out inspection for business risk problems and have done pre-examination and approval, And did not attach great importance to the assessment work, and even ignored the follow-up supervision and management work. To ensure the effective implementation of the 
supervision and management of the payment system, it is necessary to formulate the supervision and management objectives, that is, to ensure the safe and operational efficiency of the payment system, with appropriate adjustment of supervision and management ideas, the use of more effective monitoring and management tools to promote Market orderly operation.

Third, the use of subcontract supervision and management of the way leading to supervision and management of the border blurred. Internet financial management, the various supervision and management departments do not work in coordination with each other, but the division of their duties, and management functions are not clear boundaries, leading to the phenomenon of business duplication, for bills, bank cards, account supervision and management, or There is a repeat phenomenon, or there are loopholes, seriously affecting the quality of supervision and management. In the context of Internet finance, to achieve innovation management, it is necessary to supervise the management departments need to fulfill the duties clear, this cooperation between the various departments, coordination and supervision between the work to improve the quality of the supervision and management of the payment system The

The main objective of the supervision and management of the payment system is to ensure the safety of the system and reduce the operational risk of the system in order to improve the operating efficiency of the payment system. However, this kind of supervisory management goal has the goal of decreasing financial efficiency, and it is not conducive to the supervision and management system innovation. In the financial environment of the Internet of Things, it is necessary to realize the innovation of financial products and the innovation of financial market, but also to break the traditional rules of market competition, but also to encourage cooperation and encourage the combination of encouragement and norms so that the supervision and management objectives and market operation The actual match, in the Internet to improve the efficiency of financial operations at the same time, the payment system in a safe running state.

First, the current payment system supervision and management system, including the "payment settlement method" and "bill law" and so on, from the Internet financial point of view to be updated, the adaptability is not strong, is not conducive to the healthy operation of the payment system.

Second, the current level of institutional management is not high, although including the "bill law", including recourse to the legal level of management, but most of the management is still limited to the department's rules and regulations, so that the participation of Internet financial behavior can not Get legal protection.

Third, the payment system supervision and management of the existence of a blank. Although the state has introduced a variety of payment system supervision and management system, but there is still a blank. For example, in the Internet platform to carry out transfer clearing business, in the network platform to implement cross-regional payment business supervision and management are not made clear.

\section{China's payment system supervision and management of the coping strategies}

In 2016, the Internet financial into the standardized development of the track, the People's Bank of China on the Internet financial environment to pay the business played a role in supervision and management. It is necessary to adapt to the changing environment of the times, emphasizing adherence to encourage innovation and norms, improve the transparency of the supervision and management framework to ensure that the Internet finance to better development.

First, the payment system is divided into different risk levels, to take the classification supervision and management measures. The monitoring system and the reporting system to establish, to pay the full information of the information services. The supervision and management 
of the payment business shall be supervised and managed in the order of the low level to the high level according to the risk level, so that the violation of the provisions can be avoided and the supervision and management efficiency of the payment system can be improved.

Second, the payment system on-site inspection methods to improve, emphasizing the intensity of off-site monitoring, penalties will be implemented in place. By analyzing the off-site monitoring results, it is possible to understand the weaknesses in the operation of the payment business and to be able to check the risk points of the site. The department that violates the regulations and the relevant laws need to take sanctions according to the law. As the efficiency of the inspection increases, the risk of paying the industry is under control.

Internet of things financial environment, to pay the implementation of supervision and management, only to take measures to encourage innovation is not enough, but to encourage innovation at the same time, but also constantly improve the supervision and management, so that the security system to run the situation To improve the operating efficiency of the payment system to effectively control the operation of the payment system. Supervision and management is to improve the efficiency of the payment system to run the key, but also to promote the healthy development of Internet financial pendant. With the improvement of supervision and management model, supervision and management means will be adjusted according to the need to do the assessment of innovation business, to achieve the unity of supervision and management rules to ensure fair competition in the financial market. Financial, industry to actively face the supervision and management, to avoid the supervision and management caused by the cost of raising concerns. At the same time, but also the establishment of payment system supervision and management of the supporting objectives, namely, anti-money laundering, safeguarding consumer rights and interests, improve corporate credit and so on. The information disclosure system developed, the establishment of the Internet financial service center; the credit rating system to build up, and actively solve the Internet payment related to various contradictions and disputes, to respond to complaints to ensure that the Internet financial environment is benign.

In the payment system of laws and regulations developed at the same time, but also according to the actual operation of the payment system continues to improve. In accordance with the law of the Internet financial operation to the appropriate payment system supervision and management framework developed to improve the transparency of the management framework, all the management content should be clear, open, and management content to the legislative level. For example, the industry access system needs to be further improved, the Internet financial environment for the payment system involved in the principle of content to be refined to ensure that the Internet payment system in accordance with the norms of operation to ensure the healthy and orderly development of the Internet financial environment. For the supervision and management system in the management of the content and to take the necessary monitoring measures, such as network operators, practitioners, registered capital, etc., to control standards developed. For the supervision and management mechanism, such as payment assessment system, off-site monitoring system, etc., should implement strict supervision and control to ensure the benign operation of the payment system.

\section{Conclusion}

In summary, the Internet financial system, the financial industry's service quality and service efficiency has improved to meet the diverse needs of the financial market. The financial operation mode with the Internet as the carrier, including the financing, payment, loan and so on in the network financial space to complete, accordingly, the supervision and management system also 
need to make adjustments and continue to improve the financial industry more vitality and vitality The However, in such a financial operation environment, China's payment system supervision and management also formed a challenge, to take appropriate response measures is necessary.

\section{Acknowledgements}

2016 National Social Science Fund Project: 16BFX130, “Internet Financial Market Access and Risk Legal Supervision Research”.

2015 Social Science and Social Sciences of Hainan Province Social Science Planning Project: HNSK (QN) 15-46, "International Tourism Island vision under the network financial regulatory legal mechanism”.

\section{References:}

[1] Zhang Xiaobo. Internet financial regulatory principles: to explore the new financial regulatory paradigm [R]. China Banking Regulatory Commission Working Paper, 2014 (02): 6-17.

[2] Zhang Xu. Internet financial impact on commercial banks and countermeasures [J]. Finance and Taxation, 2014 (11): 39-40.

[3] Yu Zhonghua, Qi Dongzhi. Logical analysis and historical analysis of global financial supervision [J]. International Finance Research, 2013 (03): 41-47.

[4] XIE Ping, ZOU Chuan-wei, LIU Hai 2. The necessity and core principles of Internet financial supervision [J]. International Finance Research, 2014 (08): 3-9.

[5] Gao Hongye. Western economics (micro part) [M]. Beijing: Renmin University of China Press, 2013: 128-135.

[6] Xie Ping, Zou Chuanwei. Bank of macro-prudential supervision of the basic theory of research [M]. Beijing: China Financial Publishing House, 2013: 43-68,170-173. 